\title{
Uji Diagnostik Working Memory Rating Scale [WMRS] versi Bahasa Indonesia dan Proporsi Anak Sekolah Dasar dengan Kesulitan Belajar dan Defisit Working Memory di Jakarta
}

\author{
Tjhin Wiguna, Noorhana Setyawati WR, Fransiska Kaligis \\ Departemen Psikiatri Fakultas Kedokteran Universitas Indonesia/RS Dr. Cipto Mangunkusumo, Jakarta
}

\begin{abstract}
Latar belakang. Kesulitan belajar merupakan masalah tersering ditemukan pada anak dan remaja. Penelitian terakhir menunjukkan hubungan antara kesulitan belajar dan defisit working memory, namun sampai saat ini penentuan defisit working memory masih sulit dilakukan.

Tujuan. Mendapatkan alat ukur working memory yang sahih dan andal bagi guru di sekolah dasar dalam Bahasa Indonesia. Di samping itu, penelitian kami juga bermaksud mengidentifikasi besar proporsi anak dengan kesulitan belajar dan defisit working memory di Jakarta.

Metode. Penelitian uji diagnostik dan potong lintang; (1) uji diagnostik working memory rating scale (WMRS) versi Bahasa Indonesia. Sembilanpuluh sembilan anak dari 5 sekolah dasar yang dipilih secara acak proporsional; (2) Studi potong lintang untuk mendapatkan proporsi anak dengan kesulitan belajar yang disertai dan tanpa disertai defisit working memory di wilayah Jakarta. Empatratus duapuluh tiga anak dari 27 sekolah dasar di Jakarta yang dipilih secara acak proporsional.

Hasil. Titik potong WMRS versi Bahasa Indonesia pada kelompok usia 6-9 tahun, T score > 60 adalah 20 dan $T$ score $>70$ adalah 30 (sensitivitas 0,161 dan spesifisitas 0,674). Pada kelompok usia 10-12 tahun, Tscore $>60$ adalah 29 dan $T$ score $>70$ adalah 42 (sensitivitas 0,186 dan spesifisitas 0,929 ). Dari 423 anak usia sekolah dasar dengan usia rerata $9,34(1,78)$ yang diikutsertakan, didapat $104(24,6 \%)$ anak yang mengalami kesulitan belajar. Usia rerata anak dengan kesulitan belajar 9,58 (1,76). Proporsi anak sekolah dasar yang mengalami kesulitan belajar murni dengan defisit working memory 8,04\% dengan usia rerata 9,82 (1,79).

Kesimpulan. Working memory rating scale (WMRS) versi Bahasa Indonesia spesifik dalam menilai defisit working memory pada anak sekolah dasar dengan kesulitan belajar. Proporsi kesulitan belajar pada anak sekolah dasar dan defisit working memory cukup besar dan kondisi tersebut perlu menjadi perhatian agar kualitas anak dapat ditingkatkan. Sari Pediatri 2012;14(3):191-7.
\end{abstract}

Kata kunci: kesulitan belajar, working memory

\footnotetext{
Alamat korespondensi:

Dr.dr. Tjhin Wiguna, SpKJ(K), Staf Pengajar Divisi Psikiatri Anak dan Remaja, Departemen Psikiatri FKUI/RSCM, Jalan Kimia 2/35, Jakarta 10430. Telepon/Fax 021310741, 02139899128
} 
B elajar merupakan suatu proses yang melibatkan berbagai sistem dan fungsi di dalam otak, seperti sistem integrasi motorik-sensorik, fungsi kognitif termasuk konseptualisasi, dan juga fungsi bahasa. Adanya gangguan dari sistem dan fungsi tersebut membuat seorang anak mengalami kesulitan belajar dan tentunya berdampak terhadap kualitas hidupnya di kemudian hari. ${ }^{1,2}$

Kesulitan belajar merupakan masalah kesehatan mental yang utama pada anak dan remaja. Kondisi ini membuat anak sulit mencapai prestasi akademik yang diharapkan, dan dapat menimbulkan perasaan tidak percaya diri sehingga prestasi sekolah bertambah buruk. Angka kejadian kesulitan belajar bervariasi di antara negara dan kota besar di dunia. Di Amerika Serikat dilaporkan 6\%-10\% anak usia sekolah mengalami kesulitan belajar. ${ }^{3}$ Di Indonesia belum ditemukan angka yang pasti, begitu pula di Jakarta sebagai Ibu Kota Indonesia.

Istilah kesulitan belajar sendiri mempunyai berbagai definisi namun umumnya menekankan pengertian kesenjangan antara potensi dengan kemampuan akademik yang berhasil dicapai anak tanpa disertai gangguan fisik seperti gangguan fungsi pendengaran, gangguan fungsi penglihatan, disabilitas motorik, dan retardasi mental. ${ }^{3-5}$ Potensi anak ditentukan berdasarkan usia kronologis anak, kematangan fungsi intelektual, dan juga kesempatan untuk mendapatkan pendidikan sesuai dengan anak seusianya. ${ }^{5}$

Sampai saat ini belum banyak diketahui penyebab dari kesulitan belajar pada anak. Beberapa penelitian mengaitkan berbagai kondisi dengan terjadinya kesulitan belajar pada anak seperti faktor genetik, gangguan dalam integrasi sensorik-motorik, dan prematuritas. Dalam penelitian terakhir dikatakan bahwa working memory juga berperan terhadap kesulitan belajar pada anak. ${ }^{7}$

Kemampuan belajar anak sangat dipengaruhi oleh kecerdasan dan memori anak tersebut. Penelitian yang telah dilakukan membuktikan; (1) working memory penting untuk memprediksi kemampuan belajar seorang anak; (2) pengukuran working memory jauh lebih bermakna untuk menentukan kemampuan belajar anak dibandingkan nilai IQ yang hanya menunjukkan tingkatan kecerdasan; (3) terdapat hubungan antara fungsi working memory dengan kecerdasan. ${ }^{7,8}$

Working memory adalah kemampuan untuk menyimpan dan memanipulasi informasi untuk waktu yang singkat. Working memory yang optimal mem- butuhkan kemampuan memperhatikan, mengingat, dan melakukan tindakan terhadap suatu informasi yang sedang berlangsung secara bersamaan. Berbeda dengan daya ingat jangka pendek, working memory memerlukan kemampuan untuk menyimpan dan memproses informasi dalam waktu singkat sementara pada daya ingat jangka pendek murni hanya merupakan kemampuan menyimpan informasi dalam waktu singkat saja. Kemampuan working memory ini sering dimasukkan dalam kemampuan fungsi eksekutif, serta merupakan hal mendasar dalam kemampuan menyelesaikan masalah. ${ }^{9}$ Selain itu kemampuan ini juga dikaitkan dengan kemampuan anak untuk memperoleh pengetahuan dan keterampilan baru. Secara neuroanatomi kapasitas working memory ini diatur pada lobus frontalis otak. ${ }^{10}$

Dalam situasi kelas, seorang murid sangat memerlukan keterampilan working memory yang optimal untuk mengerjakan aktivitas sehari-harinya. Working memory yang buruk mengakibatkan gangguan dalam melakukan tugas sederhana seperti mengingat instruksi di kelas sampai pada aktivitas yang lebih kompleks yang melibatkan fungsi menyimpan dan memproses informasi, serta kemampuan bertahan dalam mengerjakan tugas yang lebih sulit., ${ }^{9} 10$

Anak dengan defisit working memory sering dianggap sebagai anak yang memiliki perhatian yang buruk dan mudah beralih, tanpa memiliki gejala hiperaktivitas seperti yang terdapat pada anak dengan gangguan pemusatan perhatian dan hiperaktif serta membuat anak mengalami kesulitan belajar sehingga prestasi akademik yang dicapai berada di bawah temanteman sekelasnya. ${ }^{8,9}$

Alloway ${ }^{7}$ mengatakan bahwa kecerdasan dan memori otak merupakan dua hal yang berperan penting dalam menentukan kemampuan belajar anak. Berbagai penelitian membuktikan bahwa pengukuran working memory jauh lebih bermakna untuk menentukan kemampuan belajar anak dibandingkan nilai IQ yang hanya menunjukkan tingkatan kecerdasan. Alloway, ${ }^{11}$ menyatakan bahwa dengan mengetahui kapasitas working memory seorang anak saat memulai sekolah, yaitu sekitar usia lima tahun, maka dapat diprediksikan kemampuan belajar mereka enam tahun ke depan, dan lebih jauh juga dapat diprediksikan kesuksesan anak tersebut di kemudian hari. Oleh karena itu deteksi dini gangguan working memory merupakan hal yang sangat penting sehingga dapat direncanakan intervensi sejak dini. 
Wiguna $\mathrm{dkk}^{12}$ dalam penelitian pendahuluan dengan subjek anak sekolah dasar yang datang ke klinik tumbuh kembang anak dan klinik psikiatri anak di rumah sakit dijumpai proporsi anak dengan kesulitan belajar sebesar 28\%. Dalam penelitian yang dilakukan oleh Durham University, dikatakan bahwa $10 \%$ dari 3000 anak yang diteliti mengalami gangguan working memory yang berdampak serius terhadap kemampuan belajar anak sehingga prestasi akademik yang diharapkan tidak tercapai. ${ }^{11}$

Sampai saat ini penelitian mengenai hubungan antara tingkat intelegensi dengan pencapaian akademik masih belum memberikan penjelasan yang memadai dalam menentukan tatalaksana kesulitan belajar pada anak sehingga diperlukan pemeriksaan lain untuk melihat berbagai kondisi yang melatarbelakangi kesulitan belajar tersebut demi tercapainya tatalaksana yang optimal. ${ }^{13}$

Di lain pihak, dalam kehidupan sehari-hari ternyata gangguan working memory tidak mudah dideteksi baik oleh dokter, guru, psikolog, ataupun tenaga profesional lainnya. Anak dengan defisit working memory sering dikatakan sebagai anak yang tidak mampu berkonsentrasi atau anak dengan tingkat kecerdasan kurang, sehingga mereka menjadi gagal di sekolah, tidak jarang keluar dari sekolah dan pada akhirnya akan menurunkan produktivitas serta kualitas hidup mereka di kemudian hari. ${ }^{8}$

Berdasarkan pemahaman di atas, penelitian kami bertujuan untuk mendapatkan alat deteksi dini defisit working memory pada anak usia sekolah dasar yang mudah digunakan oleh guru serta mendapatkan angka kejadian defisit working memory pada anak dengan kesulitan belajar di Jakarta. Dengan alat yang dapat menentukan defisit working memory pada anak diharapkan deteksi dini akan lebih mudah dilakukan oleh guru, sehingga penanganan terhadap masalah dapat dilakukan secepatnya dan mencegah terjadinya kegagalan anak di sekolah.

\section{Metode}

Penelitian ini menggunakan rancangan pontong lintang dan terdiri dari dua tahap

- Tahap pertama merupakan uji diagnostik terhadap instrument Working Memory Rating Scale (WMRS) untuk menentukan defisit working memory pada anak berusia 5-11 tahun. Instrumen ini dikembangkan oleh Tracy Packiam Alloway dkk pada tahun 2008 yang terdiri dari 20 pernyataan. Instrumen WMRS dapat digunakan oleh guru atau profesional lain yang mengajar anak di dalam kelas dengan masa mengajar terhadap anak yang bersangkutan minimal selama satu bulan. Setiap pernyataan dijawab dengan; tidak khas sama sekali (0), kadang-kadang (1), cukup khas (2), dan sangat khas (3).

Uji diagnostik ini melibatkan 100 anak usia sekolah dasar kelas 1-6 di lima sekolah dasar di Jakarta. Pemilihan sekolah berdasarkan pertimbangan kesiapan sekolah dalam mengikuti uji diagnostik. Kriteria inklusi adalah semua anak usia sekolah dasar dari kelas 1-6 yang tidak mengalami retardasi mental. Subjek penelitian dipilih secara acak proporsional beserta guru yang sudah mengajar anak tersebut minimal satu bulan. Orangtua subjek penelitian dan guru melalui kepala sekolah diminta untuk mengisi lembar kesediaan untuk mengikuti penelitian di tahap ini. Anak dengan kesulitan belajar didefiniskan sebagai anak dengan prestasi akademik di bawah rerata kelas namun tidak memiliki gangguan fungsi intelektual.

Tahapan uji diagnostik yang dilakukan adalah (1) menterjemahkan WMRS ke dalam Bahasa Indonesia; (2) uji coba WMRS dalam Bahasa Indonesia pada sepuluh orang guru untuk mendapatkan informasi mengenai setiap butir pernyataan dalam alat tersebut; (3) revisi WMRS berdasarkan informasi yang diberikan oleh guru; (4) uji validasi untuk menentukan nilai titik potong (receiver operator curve/ROC) berdasarkan T score. Penentuan titik potong juga dibagi dalam kelompok usia, untuk kelompok usia 6-9 tahun dan kelompok usia $10-12$ tahun. T score $>60$ (nilai rerata di tambahkan satu nilai standar deviasi) menujukkan adanya defisit working memory sedang dan T score $>70$ (nilai rerata di tambahkan dua kali nilai standar deviasi) menunjukkan defisit working memory berat, sensitivitas, dan spesifisitas WMRS versi Bahasa Indonesia; (5) uji reliabiltas berupa Cronbach's alpha dan reliabilitas test-retest setelah 3 bulan kemudian. Selain data WMRS versi Bahasa Indonesia, juga dikumpulkan data demografi singkat yang meliputi umur dan nilai rerata subjek penelitian dalam satu semester terakhir. Data dianalisis dengan menggunakan SPSS versi 16. 
- Tahap ke dua merupakan tahap penentuan besar proporsi gangguan working memory pada anak dengan kesulitan belajar di Jakarta. Tahap kedua melibatkan 423 anak usia sekolah dasar kelas 1-6 dari 27 sekolah dasar di Jakarta. Pemilihan sekolah dasar dan subjek penelitian berdasarkan acak proporsional. Penetapan jumlah subjek penelitian berdasarkan perhitungan besar sampel tunggal untuk data nominal dengan tingkat kemaknaan 5\% dan tingkat ketepatan absolut 5\%.

Kriteria inklusi subjek penelitian adalah (1) anak sekolah dasar kelas 1-6 yang mempunyai rapor semester terakhir; (2) tidak menderita penyakit fisik kronik berdasarkan anamnesa yang dilakukan terhadap orangtua anak; (3) tidak menderita gangguan mental berat seperti gangguan psikotik, gangguan depresi berat, atau gangguan mood bipolar. Kriteria eksklusi adalah jika anak mengalami retardasi mental. Untuk menyingkirkan ada tidaknya gangguan mental dilakukan wawancara psikiatrik dengan menggunakan penuntun wawancara Mini Neuropsychiatric Interview (MINI) for kid yang sudah diterjemahkan ke dalam Bahasa Indonesia.

Orangtua anak dan guru melalui kepala sekolah diminta untuk mengisi lembar kesediaan mengikuti penelitian ini. Anak dengan kesulitan belajar didefinisikan sebagai anak dengan prestasi akademik di bawah rerata kelas namun tidak memiliki gangguan fungsi intelektual. Alat ukur yang digunakan adalah WMRS versi Bahasa Indonesia yang sudah dilakukan uji diagnostik sebelumnya. Data demografi anak dan orangtua juga dicatat melalui kuesioner yang khusus dibuat untuk peneltian ini. Semua data ditabulasi dan dianalisis dengan menggunakan SPSS versi 16.

\section{Hasil}

Dalam uji diagnostik terhadap alat ukur WMRS pada 99 anak usia sekolah dasar didapatkan usia rerata anak sebesar $8,82(1,86)$ dengan rentang usia antara $6-12$ tahun (Tabel 1).

Dalam uji coba WMRS versi Bahasa Indonesia terhadap 10 orang guru sekolah dasar di Jakarta, dijumpai beberapa butir pernyataan yang dikatakan perlu perbaikan redaksional oleh guru, sebagai contoh (1) pernyataan nomor 1 yang menyatakan 'setiap akan melanjutkan ke aktivitas berikutnya, anak butuh diperingatkan beberapa kali oleh guru' direvisi menjadi 'setiap akan melanjutkan aktivitas berikutnya, anak perlu diperingatkan beberapa kali oleh guru'; (2) pernyataan nomor 2 yang menyatakan 'mengangkat tangan setiap ingin menjawab tapi lupa apa yang hendak dikatakan' direvisi menjadi 'mengangkat tangan setiap ingin menjawab tetapi anak lupa apa yang hendak ditanyakan'; (3) pernyataan nomor 12 yang menyatakan 'kebingungan dalam aktivitas yang rumit' direvisi menjadi 'anak merasa bingung dalam aktivitas yang rumit'; dsb. Setelah dilakukan perbaikan

Tabel 1. Karateristik subjek penelitian uji diagnostik $(\mathrm{n}=99)$

\begin{tabular}{lcccc}
\hline Karakteristik & $\begin{array}{c}\text { Nilai } \\
\text { minimum }\end{array}$ & $\begin{array}{c}\text { Nilai } \\
\text { maksimum }\end{array}$ & Rerata (SB) & Frekuensi (\%) \\
\hline Usia anak & 6 & 12 & $8,82(1,86)$ & \\
Nilai akademik anak & 65 & 91 & $78,40(7,01)$ & \\
$\begin{array}{l}\text { Prestasi belajar } \\
\quad \text { Kesulitan belajar }\end{array}$ & & & & $25(24,8 \%)$ \\
$\quad$ Tidak kesulitan belajar & & & & $74(74,7 \%)$ \\
WMRS & 0 & 48 & $13,40(11,27)$ & \\
\hline
\end{tabular}

Tabel 2. Nilai titik potong, sensitivitas, dan spesifisitas dari WMRS versi Bahasa Indonesia

\begin{tabular}{llccc}
\hline Kelompok usia (tahun) & \multicolumn{2}{c}{ Nilai titik potong } & Sensitivitas & Spesifisitas \\
\hline $6-9(\mathrm{n}=56)$ & $T$ score $>60$ & 20 & 0,161 & 0,674 \\
& $T$ score $>70$ & 30 & & \\
10-12 $(\mathrm{n}=43)$ & $T$ score $>60$ & 29 & 0,186 & 0,929 \\
& $T$ score $>70$ & 42 & & \\
\hline
\end{tabular}


kemudian dilakukan penterjemahan kembali ke dalam Bahasa Inggris.

Setiap butir pernyataan dijawab dengan 'tidak sama sekali (0)'; 'kadang-kadang (1)'; 'cukup khas (2)'; 'sangat khas (3)'. Jumlah nilai total WMRS dalam penelitian berada dalam rentang antara $0-48$. Uji reliabilitas internal menunjukkan nilai Cronbach's alpha sebesar 0,959 dengan jumlah butir yang dinilai sebayak 20 buah. Korelasi antar butir berkisar antara 0,189-0,777. Uji reliabiltas test-retest dengan Wilcoxonrank test menunjukkan tidak adanya perbedaan yang bermakna antara hasil pemeriksaan WMRS pertama dan 3 bulan kemudian ( $\mathrm{p}=0,950)$.

Penentuan nilai titik potong sesuai dengan dengan petunjuk alat ukur aslinya adalah berdasarkan $\mathrm{T}$ score, yaitu; (1) di bawah $\mathrm{T}$ score $<60$ dikatakan tidak ada defisit working memory; (2) T score $>60$ dikatakan mempunyai defisit working memory sedang; dan (3) diatas $T$ score 70 dikatakan mempunyai defisit working memory berat. WMRS versi Bahasa Indonesia juga terbagi dalam kelompok usia yaitu usia 6-9 tahun $(\mathrm{n}=56)$ dan usia $10-12$ tahun $(\mathrm{n}=43)$. T score $>60$ ditentukan berdasarkan nilai rerata ditambahkan nilai deviasi standar dan T score $>70$ merupakan nilai rerata ditambahkan nilai dua kali standar deviasi. Nilai titik potong WMRS versi Bahasa Indonesia dapat dilihat pada Tabel 2, Gambar 1 dan Gambar 2.

\section{Proporsi kesulitan belajar dan defisit working memory pada anak usia sekolah dasar di Jakarta}

Dari 423 anak sekolah dasar yang diikutsertakan didapatkan rentang usia antara 5-15 tahun dan nilai rerata (SD) 9,34 $(1,78)$ dengan rasio anak lakilaki: perempuan $6: 5$ (Tabel 3). Kami menemukan $104(24,6 \%)$ anak dengan kesulitan belajar dengan proporsi anak laki-laki lebih besar dibandingkan anak perempuan $(61,5 \%$ vs $38,5 \%, p=0,09)$. Umur rerata anak dengan kesulitan belajar 9,58 $(1,76)$ (Tabel 3).

Dari 104 anak dengan kesulitan belajar, dijumpai 46 anak dengan kesulitan belajar yang disertai dengan gangguan pemusatan perhatian/ hiperaktivitas (GPPH) dan $58(13,7 \%)$ anak dengan kesulitan belajar tanpa penyerta lain, yang selanjutnya disebut sebagai anak dengan kesulitan belajar murni. Anak dengan kesulitan

Tabel 3. Karakteristik subjek penelitian

\begin{tabular}{|c|c|c|c|}
\hline Karateristik & $\begin{array}{l}\text { Total subjek } \\
\text { penelitian } \\
(\mathrm{n}=423)\end{array}$ & $\begin{array}{l}\text { Subjek dengan } \\
\text { kesulitan belajar } \\
\qquad(\mathrm{n}=104)\end{array}$ & $\begin{array}{l}\text { Subjek dengan } \\
\text { kesulitan belajar murni } \\
\qquad(\mathrm{n}=58)\end{array}$ \\
\hline \multicolumn{4}{|c|}{ Umur anak (tahun) } \\
\hline Rentang & $5-15$ & $6-14$ & $7-14$ \\
\hline Rerata (SB) & $9,34(1,78)$ & $\begin{array}{c}9,58(1,76) \\
p=0,158^{*}\end{array}$ & $\begin{array}{c}9,82(1,79) \\
\mathrm{p}=0,09^{*}\end{array}$ \\
\hline \multicolumn{4}{|c|}{ Jenis kelamin anak, n (\%) } \\
\hline Laki-laki & $229(54,1)$ & $65(62,5)$ & $31(53,5)$ \\
\hline Perempuan & $194(45,9)$ & $\begin{array}{l}39(37,5) \\
\mathrm{p}=0,07^{* *}\end{array}$ & $\begin{array}{l}27(46,5) \\
p=0,89^{* *}\end{array}$ \\
\hline \multicolumn{4}{|c|}{ Suku berdasarkan ayah, n (\%) } \\
\hline Jawa & $174(41,1)$ & $32(30,8)$ & $17(29,3)$ \\
\hline Sunda & $60(14,2)$ & $17(16,3)$ & $10(17,2)$ \\
\hline Batak & $10(2,4)$ & $3(2,9)$ & $2(3,4)$ \\
\hline Betawi & $95(22,5)$ & $23(22,1)$ & $11(19,0)$ \\
\hline Ambon & $4(0,9)$ & $1(1)$ & $1(1,70)$ \\
\hline Lain-lain & $80(18,9)$ & $28(26,1)$ & $17(29,3)$ \\
\hline \multicolumn{4}{|c|}{ Status sosial ekonomi orangtua, n (\%) } \\
\hline Rendah & $30(7,1)$ & $8(7,7)$ & $7(12,1)$ \\
\hline Sedang & $369(87,2)$ & $92(88,5)$ & $46(79,3)$ \\
\hline Tinggi & $24(5,7)$ & $4(3,8)$ & $5(8,6)$ \\
\hline
\end{tabular}




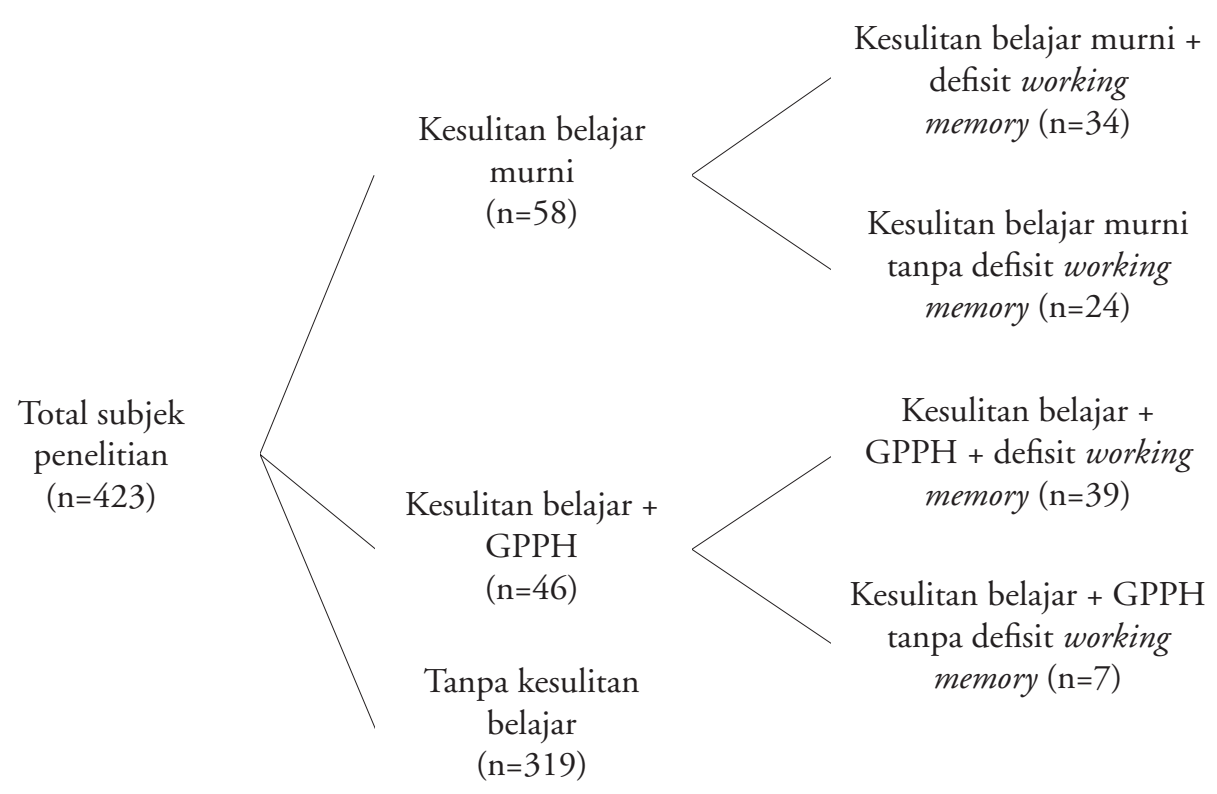

Gambar 1. Alur hasil penelitian proporsi kesulitan belajar dan defisit working memory

belajar murni yang disertai dengan defisit working memory ditemukan 34 anak (8,04\%). Usia rerata anak dengan kesulitan belajar murni 9,76 (1,81) dan tidak dijumpai perbedaan yang bermakna antara proporsi anak laki-laki dan perempuan $(\mathrm{p}=0,78)$ (Tabel 3, Gambar 1).

\section{Pembahasan}

Dari hasil penelitian kami spesifisitas instrumen WMRS versi Bahasa Indonesia cukup tinggi yaitu 67,4\% pada kelompok usia 6-9 tahun dan 92,9\% pada usia 10-12 tahun. Hal tersebut menyatakan bahwa pemeriksaan dengan WMRS versi Bahasa Indonesia pada anak yang mengalami kesulitan belajar positif, maka kemungkinan besar anak tersebut mengalami defisit working memory. Pemeriksaan tersebut tentu sangat membantu guru pengajar untuk menentukan latar belakang kesulitan belajar yang terjadi pada anak. Kondisi ini juga sangat berguna bagi orangtua sehingga tindakan dapat segera dilakukan agar kemampuan belajar anak dapat kembali berfungsi secara baik.

Berbagai kegiatan dapat dilakukan untuk mengatasi anak dengan kesulitan belajar dengan defisit working memory, seperti merangsang anak untuk selalu bertanya dan mencatat berbagai informasi yang diterimanya, terutama pada informasi yang panjang dan kompleks, memberikan berbagai stimulasi yang berkaitan dengan verbal working memory seperti bermain dengan katakata, alphabet dan juga kalimat, atau membantu anak melihat berbagai gambar, bentuk, dan angka sehingga visuospatial working memory mereka dapat berkembang. Semua alat stimulasi tersebut dirancang dalam bentuk komputerisasi sehingga menarik minat anak untuk mengikuti latihan, namun sayangnya alat-alat tersebut belum dibuat dalam versi Bahasa Indonesia sehingga penggunaannya masih sangat terbatas.

Pendekatan yang dapat dilakukan oleh guru dalam mendukung kapasitas anak dengan defisit working memory di antaranya adalah menggunakan gambar untuk mengingat cerita, meminta anak untuk menceritakan ulang dalam urutan kronologis rangkaian peristiwa dari ingatan, menggunakan kata seperti pertama-tama, kedua, selanjutnya, dan merangsang anak untuk mengenali angka yang hilang dalam urutan: $0,1,2, \ldots 4,5, \ldots .{ }^{14}$

Hasil lain dari penelitian kami terdapat proporsi kesulitan belajar 24,6\% pada anak sekolah usia 6-12 tahun di jakarta. Hasil tersebut tidak berbeda jauh dengan hasil penelitian pendahuluan kesulitan belajar pada anak sekolah dasar yang datang ke klinik tumbuh kembang anak dan klinik psikiatri yaitu 28\% ${ }^{12}$ Dengan didapatnya proporsi kesulitan belajar dan defisit working 
memory pada anak di Jakarta, menunjukkan besaran masalah yang dihadapi oleh anak usia sekolah dasar dan hal tersebut tentu tidak saja dihadapi oleh anak sekolah dasar di Jakarta, namun mungkin juga dihadapi oleh anak sekolah dasar di tempat lain di Indonesia. Dengan demikian, intervensi yang optimal tentunya perlu dirancang dan diimplementasikan pada anak dengan masalah tersebut sehingga kualitas dan produktivitas mereka dapat dikembalikan secepat mungkin.

\section{Daftar pustaka}

1. Harrison PL, Flanagan DP. Contemporary intellectual assessment: theories, tests, and issues. New York: Guilford Press; 2005. h.579.

2. Lerner, Janet W. Learning disabilities: theories, diagnosis, and teaching strategies. Boston: Houghton Mifflin; 2000.

3. Child Development Institute. About learning disabilities [Internet]. Orange, CA: Child Development Institute; 2008 [cited 2010 Dec 2]. Didapat dari: http://www. childdevelopmentinfo.com/learning/learning_disabilities.shtml

4. Mosby's Medical Dictionary, 8th edition. () 2009, Elsevier.

5. Selekman J. Learning disabilities: a diagnosis ignored by nurses. Pediatr Nurs 2002; 28:630 - 2

6. American Psychiatric Association. DSM-5 development, A12-learning disorder. 2011

7. Alloway, TP. Working memory but not IQ predicts subsequent learning in children with learning difficulties. J Psychol Assess 2009;25:92 - 8 .
8. Colom R, Abad FJ, Quiroga A, Shih PC, Mendoza CF. Working memory and intelligence are highly related constructs, but why? Intelligence 2008; 36: 584-606.

9. Tsatsanis KD. Psychological and neuropsychological assessment of children. Dalam: Martin A, Volkmar FR. Lewis's child and adolescent psychiatry a comprehensive textbook. Edisi ke-4. Philadelphia: Wolters Kluwer Lippincott Williams \& Wilkins; 2007.h.357-70.

10. Alloway TP, Gathercole S, Kirkwood H, Elliot J. The memory rating scale: A class room -based behavioral assessment of working memory. Learn Individ Differ 2009; 19:242-5.

11. Science Daily. Children's Under-Achievement Could Be Down To Poor Working Memory (Intenet). Rockville, MD: Science Daily; 2008 [cited 2010 Dec 6]. Didapat dari: http://www.sciencedaily.com/ releases/2008/02/080227205111.htm

12. Wiguna T, Wibisono S, Sudigdo S. Dampak metilfenidat kerja panjang $20 \mathrm{mg}$ terhadap perbaikan pola gejala klinis pada anak dengan gangguan pemusatan perhatian/ hiperaktivitas. Sari Pediatri 2009;11:142-8.

13. Fletcher JM, Reid Lyon G, Barnes MA, Fuchs LS. Learning disabilities: from identification to intervention. New York: The Guilford Press;2007. h.324

14. Wiguna T, Setyawati NWR, Kaligis F. Learning difficulties and working memory deficits among rpimary school students in Jakarta, Indonesia. Clin Psychopharmacol and Neuroscience 2012;10:105-9. 